ВИКОРИСТАННЯ МЕТОДИЧНОГО ПОТЕНЦІАЛУ НАРОДНИХ І АВТОРСЬКИХ КАЗОК ЯК ЗАСОБУ МОРАЛЬНО-ДУХОВНОГО ВИХОВАННЯ ДОШКІЛЬНИКІВ

\title{
APPLICATION OF METHODICAL POTENTIAL OF FOLK AND AUTHOR'S FAIRY TALES AS A MEANS OF MORAL AND SPIRITUAL EDUCATION OF PRESCHOOLERS
}

УДК 372.2

DOI https://doi.org/10.32843/2663$6085 / 2021 / 39.54$

\section{Монке О.С.,}

докт. пед. наук, доцент,

доцент кафедри сімейної та спеціальної педагогіки і психології

Державного закладу

«Південноукраїнський національний педагогічний університет

імені К.Д. Ушинського»

Таркуцяк О.І.,

магістрант кафедри сімейної та

спеціальної педагогіки і психології

Державного закладу

«Південноукраїнський національний

педагогічний університет

імені К.Д. Ушинського»

\begin{abstract}
у статті представлено короткий огляд психолого-педагогічних досліджень щодо значення казки в морально-духовному вихованні дошкільників. Зазначається, що усвідомлення і розуміння переживань інших людей або переживань літературних персонажів стає основним методом формування почуттів і емоцій дитини, долучення до суспільної моралі. Але натепер є гостра потреба в обізнаності всіх, хто причетний до виховання, зокрема до моральнодуховного виховання молодого покоління, з основними етичними рисами особистості в їхньому полярному вираженні. На жаль, у сучасному вихованні відсутній етикопонятійний порядок - його нормативна злагодженість, що знижує й сам перетворювальний процес, негативно відбивається на практиці. Наявна також необхідність у створенні хрестоматії, яка за своїм змістом відповідала б меті виховання етичних рис з відповідними їм духовними цінностями, містила народні й авторські казки української і світової літератури з відповідними морально-духовними імперативами. Адже казка, як універсальний розвивальнонавчальний засіб, виводить дитину за межі безпосереднього сприймання, занурює ї в інші можливі світи із широким спектром моделей людської поведінки, орієнтує їі в соціумі. Входження дитини дошкільного віку в барвистий світ казки - явище не просте, це не тільки засіб отримання необхідної інфоормації, а й середовище спілкування, самопізнання, збагачення знаннями про життя та долі різних людей $i$, звичайно, джерело насолоди. У статті виокремлено народні й авторські казки з вираженими морально-духовними імперативами, які сприяють формуванню в дітей усвідомлення етичних рис в їхньому полярному значенні, а значить, і духовних чінностей. Ключові слова: казка, народна казка, авторська казка, морально-духовне виховання, морально-духовний імператив, духовні цінHocmi.
\end{abstract}

The article presents a brief overview of psychological and pedagogical research on the importance of fairy tales in the moral and spiritual education of preschoolers. It is noted that the awareness and understanding of the experiences of other people or the experiences of literary characters becomes the main method of forming the feelings and emotions of the child, involvement in public morality. But today there is an urgent need for awareness of all those involved in education, in particular for the moral and spiritual education of the younger generation in the basic ethical traits of the individual in their polar expression. Unfortunately, in modern education there is no ethical and conceptual order - its normative coherence, which reduces the transformation process itself and is negatively reflected in practice. There is also a need to create a textbook, the content of which would meet the purpose of educating ethical traits with their corresponding spiritual values, including folk and author's tales of Ukrainian and world literature with appropriate moral and spiritual imperatives. After all, a fairy tale, as a universal developmental and educational tool, takes a child beyond direct perception, immerses him in other possible worlds with a wide range of models of human behavior, orients him in society. The entry of a preschool child into the colorful world of fairy tales is not an easy phenomenon, it is not only a means of obtaining the necessary information, but also an environment of communication, self-knowledge, enrichment of knowledge about life and destiny of different people and, of course, a source of pleasure. The article highlights folk and author's tales with pronounced moral and spiritual imperatives, which contribute to the formation of children's awareness of ethical traits in their polar meaning, and hence spiritual values.

Key words: fairy tale, folk tale, author's tale, moral and spiritual education, moral and spiritual imperative, spiritual values.
Постановка проблеми в загальному вигляді. Художня література, зокрема казки, відіграє одну 3 найважливіших ролей у формуванні особистості дитини, у створенні системи особистісних цінностей, які в майбутньому декларуватимуться нею. Народні й авторські казки, які містять величезну кількість відомостей про навколишній світ, навіть дещо вивищуються над власним досвідом кожної окремої людини, який обмежений часом і простором. Дитині дошкільного віку, надзвичайно чутливій до зовнішніх подразників, емоційного впливу, казки допомагають розібратись у тому, як варто або не слід поводитися в соціумі. Педагогам і батькам важливо навчитися правильно фрормувати коло дитячого читання, адже казки, за умови правильного їх добору, можуть охопити якщо не все, то більшу частину навчально-виховних тем, які необхідно засвоїти дітям. Окрім цього, важливо навчити дитину міркувати над казкою й отримувати задоволення від цих роздумів. Адже майбутній читач у дитині дошкільного віку формується тоді, коли він разом із дорослим обмірковує прочитане, шукає відповіді на важливі для нього питання.

Аналіз останніх досліджень і публікацій. Проблемі морально-духовного виховання, зокрема фрормуванню в дітей етичних рис і духовних цінностей, присвячені дослідження сучасних учених у галузі психолого-педагогічної науки (І. Бех, А. Богуш, Н. Гавриш, С. Кононко, О. Монке), у яких підкреслюється значення художньої літе- 
ратури в морально-духовному вихованні дітей, формуванні позитивних етичних рис, тобто духовних цінностей. Зазначається, що усвідомлення і розуміння переживань інших людей або переживань літературних персонажів стає основним методом формування почуттів та емоцій дитини, долучення до суспільної моралі. А залучення уваги дитини до емоційного стану інших людей відбувається через читання відповідних творів та їх подальше обговорення, розпізнавання емоцій інших за фротографіями або картинками тощо.

Виділення не вирішених раніше частин загальної проблеми. Однак нині наявна гостра потреба в обізнаності всіх, хто причетний до виховання, зокрема до морально-духовного виховання молодого покоління, з основних етичних рис особистості в їхньому полярному вираженні, тобто всі «етичні поняття, якими опікується науково доцільне виховання, мають використовуватися в їхніх протилежностях - позитивних і негативних смислах» [2 с. 48). Адже за цієї умови в дітей формується внутрішнє розуміння для «смислового порівняння виховних ситуацій, учинків, у яких втілюються відповідні етичні риси, відбувається більш глибоке розумове усвідомлення, яке створює <...> їі особистісну позицію» [2 с. 48]. Окрім цього, позитивні етичні риси можна класифрікувати як відповідні духовні цінності. На жаль, у сучасному вихованні, як зауважує І. Бех, «відсутній етикопонятійний порядок - його нормативна злагодженість, що знижує й сам перетворювальний процес», негативно відбивається на практиці [2, с. 48].

Аналіз хрестоматій для дітей дошкільного віку («Хрестоматії дитячої класики від 2 до 6 років» (2010 р.), «Велика хрестоматія для малят» (2010 р.), «Велика хрестоматія для читання в дитячому садку» (2013р.), «Хрестоматія для читання в дитячому садку від 4 до 6 років» (2010р.), «Читанка-хрестоматія для читання в дитячому садку: Сонечко» видавництва «Богдан» (2012р.), хрестоматії видавництва «Основа» (уклад. А. Ємець, О. Коваленко, О. Шапка, 2017 р.), хрестоматія для дітей старшого дошкільного віку «Стежинки у Всесвіт» (уклад. К. Крутій, 2011 р.), хрестоматії видавництва «Перо» («Найкраща хрестоматія для читання дітям від 1 до 6 років» (2011р.), «Найкраща книга для читання від 1 до 3 років» (2011р.), «Найкраща книга для читання від 3 до 6 років»), «Весела скарбничка дідуся Сміховика: літературно-художня збірка для читання дітям дошкільного віку» (І. Попова, А. Богуш, 2016 р.), тематичний збірник «Соняшникова читанка: хрестоматія для читання дітям раннього та дошкільного віку» (упор. Л. Калуська, 2014 р.)) засвідчив, що в них немає підбірки творів, які були б спрямовані на виховання базових моральних якостей, визначених освітніми програмами. Переважно автори рекомендують твори для розвитку мовлення дітей. Педагог повинен само- стійно підбирати вірші, оповідання, казки до кожної моральної якості. Однак у зв'язку з різноманіттям літератури, нестачею часу, невмінням здійснювати глибокий аналіз ідеї художнього твору у вихователя ЗДО така свобода у виборі художніх творів викликає складнощі. Адже для того, щоб дібрати твір відповідно до певної духовної або моральної якості, педагогу потрібно заздалегідь перечитати всі запропоновані твори у хрестоматіях. Вибрати серед них ті, у яких яскраво ця якість представлена і доступно пояснена, відповідно до віку дітей [7].

Мета статті. Проаналізувати методично-виховний потенціал окремих народних і авторських казок із метою морально-духовного виховання дошкільників, а саме виокремити казки, які б репрезентували етичні риси в їхньому полярному вираженні, сприяли фрормуванню в дітей духовних цінностей.

Виклад основного матеріалу. Казка, як універсальний розвивально-навчальний засіб, виводять дитину за межі того, що сприймається нею безпосередньо, занурює її в інші можливі світи із широким спектром моделей людської поведінки, орієнтує її. Входження дитини дошкільного віку в барвистий світ казки - явище непросте, це не тільки засіб отримання необхідної інформації, а й середовище спілкування, самопізнання, збагачення знаннями про життя та долі різних людей і, звичайно, джерело насолоди [7].

Розкриття вихователем внутрішнього світу дорослих або однолітків сприяє фрормуванню в дитини надзвичайно важливого із соціального погляду морально-духовного світорозуміння, яке виражається передусім у можливості дитини зрозуміти іншого, угледіти в діях моральний учинок, дати йому пояснення щодо усталених норм і правил, самій відчути переживання іншого [7].

Уже в перші роки життя малюк, якого ознайомлюють із казками, активно навчається, пізнає світ дорослих, хоча ще не усвідомлює фракту такого навчання. Діти дошкільного віку схильні до запозичення окремих рис характеру та копіювання стилю поведінки дорослих. Усвідомлена дошкільником мораль художнього твору знаходить своє відображення в судженнях, суперечках, розмовах, а усвідомлення одержаних вражень, оцінка поведінки казкових персонажів допомагає дітям осмислити свої власні вчинки [7].

У процесі сприйняття казки відбувається перенесення почуттів та емоцій щодо іï персонажа в реальні життєві ситуації. Діти бачать стан іншого, співпереживають йому, ставлять себе на його місце, програють улюблені казки у своїх іграх. Усе це створює умови для розвитку в дитини здібності до співпереживання, екстраполяції сприйняття на життєві ситуації, аналогічні казковим за своєю моральною суттю. Казка трансорормує в дітях морально-духовні цінності, як-от співчуття, шанобливість, дружба, взаємодопомога, чуйність, любов, милосердя тощо [7]. 
Однак під час використання казки в навчальновиховному процесі передусім треба пам'ятати про самоцінне ії значення для загального розвитку й освіти дітей. Виховний вплив казки здійснюється насамперед через естетичне в ній [7]. О. Запорожець зауважував, що вплив правильно організованого естетичного сприйняття на духовний розвиток дитини полягає в тому, що це сприймання не тільки приводить до надбання окремих знань і вмінь, до формування окремих психічних процесів, але і змінює загальне ставлення до дійсності, сприяє виникненню нових, вищих мотивів діяльності дитини [3, с. 74]. Нові мотиви діяльності, що виникають у дошкільника у зв'язку із загальними змінами мотивів у цьому віці, фрормуються не за законами біологічного дозрівання, а залежно від тих суспільних умов, у яких живе дитина, від тієї ідейної атмосорери, у якій вона перебуває, від системи її виховання [3, с. 74].

Казки за ступенем складності не просто повинні бути «підлаштовані» під наявний рівень дитячого сприйняття, а й мають створювати «напруження душі», тобто просувати дітей на крок уперед в їхній розумовій та емоційній роботі [4, с. 38]. Персонажі художніх творів для дошкільників мають прості характеристики, побудовані на противазі: добрий - злий, трудолюбивий - лінивий, чесний брехливий тощо. Але варто також урахувати, що протягом дошкільного дитинства малюк опановує все більше відтінків у характеристиці як персонажів творів, так і подій у них. Окрім білої і чорної фрарб, у змалюванні героїв творів з'являються й інші проміжні фрарби, які поступово помічають діти дошкільного віку, починають виносити свої неоднозначні присуди й різноманітні оцінки [7].

Поетико-прозаїчна природа казки відкриває широкі можливості для педагога-практика, який у процесі занять може ініціювати як поетичні, так і прозаїчні здібності слухачів. Будь-яка казка $€$ орієнтованою на соціально-педагогічний ефект: вона навчає, виховує, запобігає, спонукає до діяльності і навіть лікує. Інакше кажучи, потенціал казки багатший, ніж її художньо-образна значущість [7]. Так, казкотерапія більше зорієнтована на дітей дошкільного віку тому, що вони ще не здатні оцінити події, які відбуваються в реальному житті, та проаналізувати їх для ухвалення самостійних рішень. Дошкільники потребують допомоги дорослих. Але і дорослі не завжди вчасно можуть зрозуміти деякі негаразди в житті дітей, адже не завжди мають відповідь на те, що саме спонукало дитину так вчинити. Під час гри, перевтілюючись у казкового героя, малюк може спокійно розповісти про свої почуття, думки. Саме під час сеансів казкотерапії діти засвоюють необхідні моделі поведінки, вчаться реагувати на життєві ситуації, підвищують рівень знань про себе й оточення, тому що казки зрозуміліші їм порівняно з поясненнями педагогів та батьків [7].
Казкові колізії, які легко сприймаються дітьми й усвідомлюються ними, є справжньою школою збагачення духовного досвіду і моральності, яка навчає розрізняти хороше і погане, виховує віру в добрі вчинки. Працюючи 3 казкою, необхідно разом із дітьми добиратися до ії сокровенного морально-духовного сенсу [7].

Насамперед педагогам і батькам треба не тільки знати, а й глибоко усвідомлювати зміст основних морально-духовних цінностей, які варто виховувати в дітей. Як зауважує І. Бех, «віра особистості в свою сутність приводить також до зменшення поведінкових коливань, що можуть спричинитись тими чи тими етично деструктивними ситуаціями <...> [1, с. 4]. Окрім цього, духовно досконала особистість має сталий внутрішній стрижень, який захищає їі від усіх зовнішніх негараздів, дозволяє «вступити на нестандартний шлях», що пов'язаний із зовнішніми і внутрішніми труднощами і міжособистісним непорозумінням», сприяє досягненню соціальних цілей $[1$, с. 5]. Учений наголошує на тому, що кожній особистості треба пройнятися й усвідомити велику ідею про те, що «люди народжені один для одного», що «рівною мірою передбачає, що всі ми народжені й для суспільства» [1, с. 18]. Лише в такому поєднані людина здатна бути щасливою. І. Бех сорормулював 62 етичні терміни для виховання [2, с. 49]. Знання означених термінів, які $є$ уособленням етичних рис в їхній полярності та водночас кваліфікуються як відповідні духовні цінності, є надзвичайно важливим для усвідомлення і вивчення. Особливо ці духовні цінності рясніють у художній літературі, зокрема в казках.

Так, у навчальному посібнику «Світова література для дітей дошкільного віку: морально-ціннісні імперативи» (О. Монке) представлено аналіз творів світової літератури з акцентом на їхньому впливі на морально-духовне виховання особистості, авторські казки світової літератури у вигляді рекомендаційного списку, складеного у хронологічному порядку і з визначенням вікової аудиторії читачів (слухачів), з виокремленням у кожній 3 них основних моральних і духовних імперативів. У рекомендаційний список авторських казок світової літератури, складений відповідно до історичного періоду, вміщено як твори для короткого читання, так і твори для тривалого читання, які читають дітям частинами [6].

Однак наявна потреба більш чітко виокремити, 3 якою метою який твір можна почитати. Зауважимо, що для читання дітей дошкільного віку поширені й авторські (літературні) казки, і казки різних народів світу, з вираженими морально-ціннісними імперативами, тобто морально-духовними настановами, «безумовними моральними веліннями, всеохоплюючими моральними законами, внутрішньо притаманними кожній людині (фундаментальний моральний принцип Канта); морально-духо- 
вна настанова, побудована на духовних правилах життя» [6, с. 35; 6, с. 17].

Окрім цього, у багатьох авторських і народних казках висвітлені відразу кілька полярних цінностей, які передаються через образи персонажів, їхню поведінку, учинки, ситуації. Так, наприклад, у казкових повістях «Чарівник Смарагдового міста» О. Волкова, «Чарівник країни Оз» Френка Баума, «Чудесна мандрівка Нільса Гольгерсона з дикими гусьми», казці «Горбоконик» П. Єршова тощо діти знаходять розуміння, що таке добродійність і зловмисність, вірність і віроломство, людяність і гордовитість, любов і ненависть, справедливість і упередженість, прямодушність і хитрість, щедрість і скупість, поступливість і упертість, серйозність і легковажність тощо. Але в більшості народних і авторських казок ми спостерігаємо одну - дві полярні етичні риси персонажів, на яких робиться акцент.

Формат статті не дозволяє проаналізувати величезну кількість народних і авторських казок у сенсі наявності в них певного морально-духовного імперативу, виражених у них духовних цінностей, які почасти виявляються в етичних рисах персонажів казок. Однак представимо деякі 3 них відповідно з виховним глосарієм І. Беха, проаналізуємо деякі народні й авторські казки української і світової літератури.

Так, чітко показано полярні етичні риси і відповідні їм духовні цінності «добродійність - зловмисність» в українських народних казках («Телесик», «Дідова дочка і бабина дочка», «Про Правду і Кривду»), в арабській казці «Кішка та сокіл», у російській казці «Як Весна Зиму здолала», у персидській казці «Принцеса і падишахів син», в афрганській казці «Хитрощі» тощо.

Надалі проаналізуємо деякі авторські казки української і світової літератури, спрямовані на різнобічне виховання духовності дітей дошкільного віку, виходячи з того, що педагог добирає художній твір залежно від конкретних педагогічних завдань, які стоять перед ним. У нашому випадку це фрормування усвідомлення полярних етичних рис і відповідних їм духовних цінностей, усвідомлення морально-духовного імперативу.

Зазначимо, що під час добору художніх творів для читання дітям варто пам'ятати передусім про їхню художню цінність. Іван Франко вважав, що спочатку доцільно знайомити дітей з людськими взаєминами через казкові форми, бо «гола правда життя» може бути занадто болючою для них. Казка ж передає дитині мудрий народний погляд на життєві конорлікти, оптимістичну віру в перемогу добра і правди. Сприймаючи казкових героїв, сміючись над ними або співчуваючи їм, дитина винесе звідси уявлення про людські чесноти, гідність і справедливість. Так, у казці Івана Франка «Заєць і Їжак» діти дізнаються про те, що повага це добре, а презирство - навпаки. Усвідомлюючи ідейну суть цієї казки, дитина починає розуміти просту духовну істину, відкриту їй автором: «Ніколи не підіймай на сміх бідного чоловіка, хоч би се був простий, репаний Їжак» [5, с. 142]. У казці «Лисичка і Журавель» викривається хитрість, догідливість улесливої Лисиці, і прямодушність та щирість Журавля. Своєю відповідною поведінкою Журавель ніби доводить, що не варто сприймати доброту і щирість за недолугість, що добро має бути «з кулаками», провчає нещирість встановленням свого морального імперативу: «стався до інших так, як би ти хотів, щоб вони ставились до тебе». Усвідомлення означеного стає доступним дітям після читання цієї казки.

Зазначимо, що в багатьох казках І. Франка сильний, хитрий і підступний звір зустрічається зі слабким і чесним. Проте підступність завжди викривається, а хижак несе заслужену кару. Так, у казці «Вовк, Лисиця і Осел» чесний і довірливий Осел розгадує злі наміри противників і врятовує своє життя, а злодії гинуть. Казка «Кролик і Ведмідь» закінчується перемогою лісової дрібноти над сильними і хижими мешканцями лісу. Розділяючи радість переможців, дитина дійде висновку, що завдяки єднанню, колективній мудрості можна захистити правду і справедливість. Моральновиховні ідеї закладені І. Франком і в казочки для наймолодших дітей («Киця», «Ріпка»). Ці ідеї він поглиблює в дусі християнської етики в казці - «Суд святого Николая». Ця казка навчає дітей уже не просто шанувати менших (як у «Ріпці») чи співчувати скривдженим (як у «Киці»), а безкорисливо допомагати знедоленим, немічним чи хворим [5, с. 143].

Родинні читання або читання в умовах ЗДО дають дитині змогу подумки брати участь у житті персонажів, ставати на бік добрих і мужніх, жаліти скривджених. Важливо, щоб діти не просто «проковтнули» прочитане, а й пропустили його крізь себе. А для цього потрібно допомогти їм краще усвідомити поведінку героїв, переглянути і прокоментувати малюнки, загострити увагу на етичних рисах дієвих осіб. Для цього можна використовувати твори для дітей М. Коцюбинського, у яких «дається непряма оцінка тих чи тих вчинків людей, народне розуміння таких моральних категорій, як добро і зло, впертість і поступливість, чесність і брехливість, працелюбність і ледарство» [5, с. 152]. Так, у казках «Про двох цапків» та «Дві кізочки» автором чітко зображено такі негативні риси, як упертість, гордість та непоступливість, які порівнюються з позитивними - поступливістю й винахідливістю. «Івасик та Тарасик» (добродійність - зловмисність), оповідання [5, с. 152].

У казці Миколи Трублаїні «Про дівчинку Наталочку та сріблясту рибку» розповідається про маленьку сріблясту рибку, яку хотів з"їсти великий білий лебідь (безжалісність), та про маленьку дівчинку (милосердність, щедрість), яка зарадила цій біді, віддавши свої черевички для спасіння рибки. Казка Миколи Трублаїні у про- 
стій формі допомагає усвідомити дитині досить складну духовно-ціннісну властивість особистості - альтруїзм [5, с. 254].

Усі без винятку казки В. Сухомлинського несуть потужний морально-духовний потенціал. Так, проблема взаємозв'язку природи і людини, бережливе ставлення до навколишнього світу, любов до рідної землі розкриваються в казках «Соловей і Жук», «Деркач і Кріт», «Камінь», «Дуб під вікном», «Флейта і Вітер», «Весняний вітер» тощо [5, c. 259-265].

В. Сухомлинський цілу низку казок присвячує темі шанобливого ставлення до старших. Так, повагу і любов до мами, що завжди було яскравою особливістю нашої національної культури, духовності, віддзеркалено в казках: «Найгарніша мама», «Казка про Гуску», «Сьома дочка», «Яблуко в осінньому саду» та інших. Любов матері до своїх дітей завжди безкорислива. Ця тема простежується й у казках «Лисиця й Миша», «Сьома дочка», «Кому ж іти за дровами» тощо. Шанобливе ставлення до батька і матері, людяність висвітлено в казці «Для чого бути Людиною», де розповідається про чоловіка, що доглядає за могилою Батька. Цвіркун не може цього зрозуміти, запитує - навіщо? Тоді чоловік відповідає: «Для цього треба бути Людиною». Тут порушена проблема стосунків між дітьми і батьками, повага до старших і пам'ять про них, яку так важливо сфрормувати в дітей [5, с. 264].

Відомо, що найбільш значуще людське почуття, яке робить людину людиною, - совість. Непросто ссрормувати усвідомлення його сутності в дошкільників. Досягається це поступово, у результаті переживання дитиною різних моральноетичних ситуацій, у яких проявляється ії або чиясь совість. Василь Сухомлинський у казці «Як Наталя у лисиці хитринку купила» дає дітям уявлення про совість у протиставленні з підступністю, які одна 3 одною не сумісні [5, с. 263].

Дошкільне дитинство не уявляється без читання авторських і фрольклористичних казок Шарля Перро і братів Грімм, неймовірно глибоких казок Г.Х. Андерсена, віршованих казок О. Пушкіна, В. Жуковського, П. Єршова й інших класиків казки [6]. Так, казки Ганса Християна Андерсена («Снігова королева», «Дикі лебеді» й інші) володіють величезним морально-духовним потенціалом, адже просякнуті непереможною силою християнської любові і показують ії оборотну сторону ненависть. Так само казки О. Пушкіна захоплюють розум маленьких читачів, закладають у них перші неусвідомлені паростки досить складних морально-духовних понять: жадібність, примхливість і надмірна вимогливість призводять до того, що «залишаєшся ні з чим» («Казка про рибака та рибку»), любов перемагає ненависть («Казка про мертву царівну і про сімох богатирів» та інші). Любов і повага до природи стверджувалась у казках М. Пришвіна, В. Біанкі, К. Паустовського, які навчають доброті і любові до братів наших менших, піклуванню і милосердю до тих із них, хто потрапив у біду. Природну красу людяності відчув і втілив в образах казки «Горбоконик» П. Єршов. Ця казка навчає дітей мудрості та моральності, які присутні навіть у її образності, звучності, живописній соковитості усного народного мистецтва, народного театру з його пластичністю і символічною глибиною і влучністю [6].

Висновки. Загалом українська і світова література багата на авторські казки, які так чи так спрямовані на морально-духовне виховання дітей. 3-поміж них виокремимо також казки С. Аксакова, П. Бажова, Ю. Бауер, Д. Біссета, Я. Бжехви, Дж. Баррі, М. Вагнера, О. Волкова, В. Гаршина, Е. Гофмана, В. Гауфра, Д. Гліорі, В. Даля, Кейт Ді Камілло, Дж.Р. Кіплінга, Л. Керролла, С. Козлова, С. Лагерлеф, Д. Мамина-Сибіряка, М. Метерлінка, В. Одоєвського, Антонія Погорельського, Л. Толстого, О. Толстого, М. Пляцковського, В. Сутеєва, О. Пройслера, К. Чуковського, Г. Циферова, О. Вайльда, які спрямовані не тільки на моральнодуховне виховання дитини, а й звертаються до душі дорослої людини.

Величезна кількість народних і авторських казок української і світової літератури вимагає певного упорядкування їх у контексті проблеми, зазначеної у статті. Саме тому на допомогу батькам і вихователям убачаємо необхідність створення спеціального виховного глосарія і хрестоматії з підібраними художніми творами, які б репрезентували етичні риси в їхньому полярному вираженні, сприяли усвідомленню моральнодуховних імперативів та фрормуванню в дітей дошкільного віку духовних цінностей.

\section{БІБЛІОГРАФІЧНИЙ СПИСОК:}

1. Бех І. Особистість у психовиховному дискурсі. Методист. Для ключових людей освіти. 2020. № № 11-12. С. 107-108.

2. Бех І. Виховний глосарій у полярному поданні. мemoдист. Для ключових людей освіти. 2020. №№ 11-12. С. 107-108.

3. Запорожец О. Избранные психологические труды : в 2-х т. Москва : Педагогика, 1986. Т. 1 : Психология восприятия ребёнком-дошкольником литературного произведения. С. 66-77.

4. Короткова Н. Художественная литература в образовательной работе с детьми старшего дошкольного возраста. Дошкольное воспитание. 2001. № 8. C. 34-41.

5. Монке О. Українська література для дітей дошкільного віку : навчальний посібник. Одеса : видавець М.П. Черкасов, 2010. 349 с.

6. Монке О. Світова література для дітей дошкільного віку: морально-ціннісні імперативи : навчальний посібник. Одеса : Чорномор'я, 2018. 214 с.

7. Монке О. Теоретико-методичні засади підготовки майбутніх вихователів до морально-духовного виховання дошкільників засобами художньої літератури : дис. ... докт. пед. наук: 13.00.08. Київ, 2020. 537 c. 